\title{
The Active Volcanoes of Kamchatka and Paramushir Island, North Kurils in 2007
}

\author{
O. A. Girina, S. V. Ushakov, N. A. Malik, A. G. Manevich, D. V. Mel'nikov, \\ A. A. Nuzhdaev, Yu. V. Demyanchuk, and L. V. Kotenko \\ Institute of Volcanology and Seismology of the Far East Division of the Russian Academy of Sciences, \\ 9 Piipa Boulevard, Petropavlovsk-Kamchatskii, 683006 Russia \\ Received March 6, 2008
}

\begin{abstract}
Eight strong eruptions of four Kamchatka volcanoes (Bezymyannyi, Klyuchevskoi, Shiveluch, and Karymskii) and Chikurachki Volcano on Paramushir Island, North Kurils took place in 2007. In addition, an explosive event occurred on Mutnovskii Volcano and increased fumarole activity was recorded on Avacha and Gorelyi volcanoes in Kamchatka and Ebeko Volcano on Paramushir Island, North Kurils. Thanks to close cooperation with colleagues involved in the Kamchatkan Volcanic Eruption Response Team (KVERT) project from the Elizovo Airport Meteorological Center and volcanic ash advisory centers in Tokyo, Anchorage, and Washington (Tokyo VAAC, Anchorage VAAC, and Washington VAAC), all necessary precautions were taken for flight safety near Kamchatka.
\end{abstract}

DOI: $10.1134 / \mathrm{S} 0742046309010011$

\section{INTRODUCTION}

The comprehensive monitoring of active volcanoes in Kamchatka and North Kurils is carried out under the KVERT project $[2,4,5]$ in close cooperation with colleagues from the Institute of Volcanology and Seismology (IVS) of the Far East Division of the Russian Academy of Sciences, the Kamchatka Branch of the Geophysical Survey (KBGS) of the RAS, and the Alaska Volcano Observatory (AVO), USA. The monitoring of volcanoes involves daily analysis of their seismic activity carried out by the KBGS, visual observations, both from field surveys close to volcanoes and by video cameras directed at the Klyuchevskoi, Shiveluch, and Bezymyannyi volcanoes (operated by the KBGS), and satellite information for recognition of thermal anomalies, ash ejection, ash and steam-gas plumes.

In 2007 six strong explosions of four Kamchatka volcanoes (Bezymyannyi, Klyuchevskoi, Shiveluch, and Karymskii) and two of Chikurachki Volcano of North Kurils took place. In addition, an explosive event occurred on Mutnovskii Volcano, and higher fumarole activity was observed on Avacha and Gorelyi volcanoes in Kamchatka as well as on Ebeko Volcano, Paramushir I., North Kurils. We indicate the Greenwich Time of events (Universal Time Standard); the local time is Greenwich +12 hours.

\section{KAMCHATKA}

Shiveluch Volcano $\left(56^{\circ} 39^{\prime} \mathrm{N}, 161^{\circ} 21^{\prime}\right.$ E, elevation $3283 \mathrm{~m}$ ) is the most northern Kamchatka volcano and is very active. The current eruptive activity cycle started in 1980 and is continuing at present. For one year and two months in 2005-2006 the volcano remained relatively quiet, up to December 4, 2006. The extrusiveexplosive eruption of Molodoi (Young) Shiveluch Volcano commenced on that date, with a strong ash ejection, and continued during all of 2007.

During the entire year, each week the KVERT published the following hazard prediction for aircraft: "The growth of the lava dome continues with viscous lava squeezing. Strong explosive activity with ash ejection up to $10 \mathrm{~km}$ above sea level (ASL) may occur at any time. Ashfalls are possible in the nearest settlements. The volcanic area is dangerous for international and local flights due to possible ash and aerosol plumes." This forecast proved to be true as long as a large thermal anomaly was constantly observed in the area (Fig. 1a) indicating the constant squeezing of the magmatic substance. The Aviation Color Code of the volcano (ACC) was largely orange (see http:// www.kscenet.ru/ivs/kvert.color.html.)

According to seismological data of the KBGS [8], ash ejections of up to $5.5 \mathrm{~km}$ ASL occurred weekly in January-February. In January-February video and visual observations recorded a steam-gas column with a minor ash admixture (up to $6 \mathrm{~km} \mathrm{ASL}$ ); plumes propagated as far as $160 \mathrm{~km}$ to the east, northeast, west, northwest and southwest from the volcano. On January 4 , fresh incandescent pyroclastic material was noted at the foot of the lava dome within $2-3 \mathrm{~km}$ from it. On January 24, at 21:25 UTC an ashfall was recorded by surface observations $20 \mathrm{~km}$ west of the volcano; the ash layer thickness was about $1 \mathrm{~mm}$.

The strongest ash ejection in the 26-year-long eruptive activity of Shiveluch Volcano took place on March 


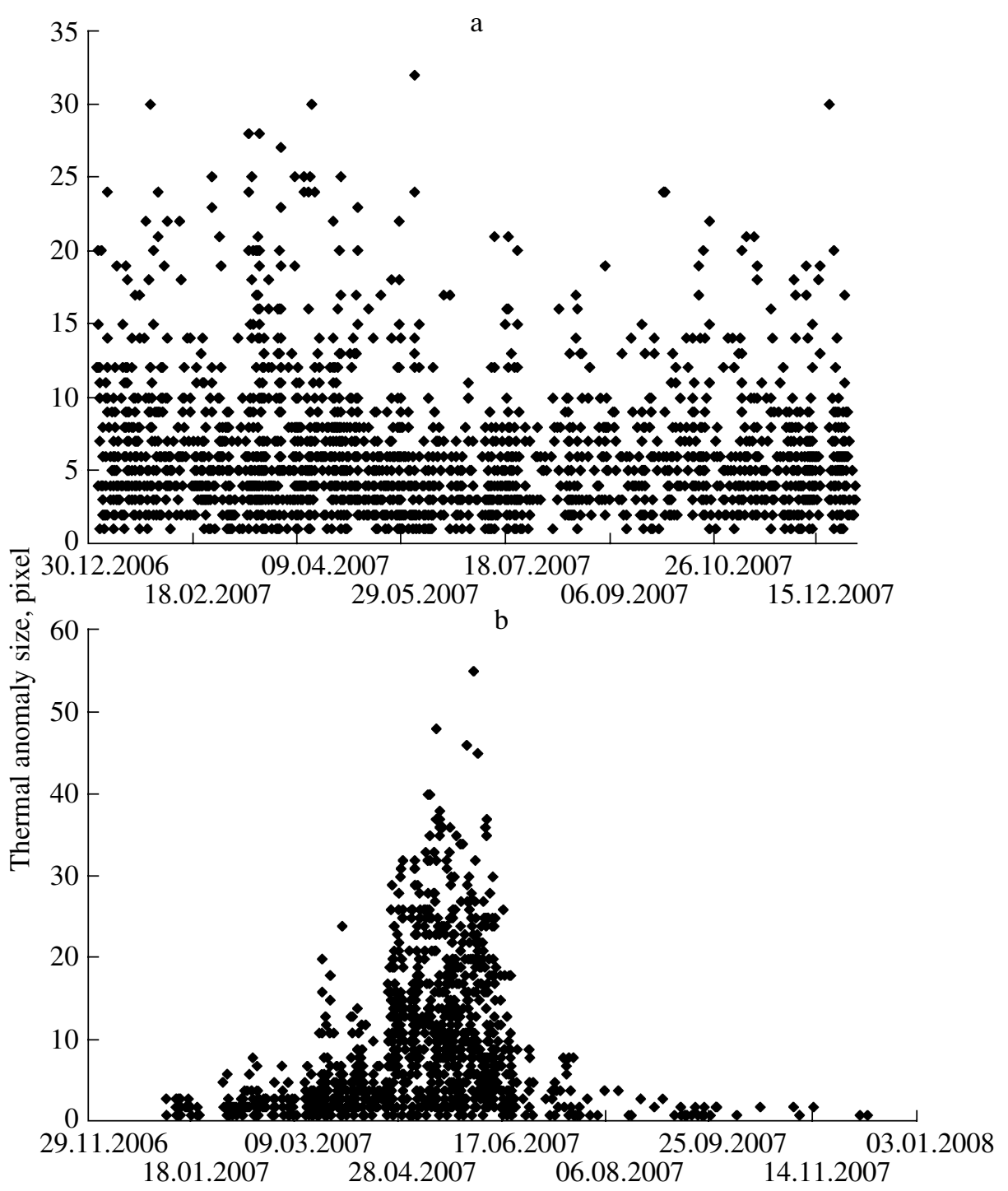

Fig. 1. Change of thermal anomaly sizes on the Shiveluch (a), Klyuchevskoi (b), Bezymyannyi (c), and Karymskii (d) volcanoes during 2007 (satellite data by KVERT IVS, the AVO, and KVERT KBGS).

29. The ash plume rose up to $12 \mathrm{~km}$ ASL (Fig. 2a), extending for $200 \mathrm{~km}$ to the northeast of the volcano. In the central sector of Molodoi Shiveluch Volcano small pyroclastic flow deposits were formed.

According to the seismological data of the KBGS [8], each week in April ash ejections with ash rising up to $7 \mathrm{~km}$ ASL took place; on April 22 an explosion up to $9 \mathrm{~km}$ ASL may have occurred. In May ash ejections up to $8 \mathrm{~km}$ ASL were recorded repeatedly, on May 2 possibly up to $10 \mathrm{~km}$ ASL; in June, up to $6.5 \mathrm{~km}$ ASL; in July repeatedly up to $6.5 \mathrm{~km}$ ASL, on July 23 possibly up to $8.3 \mathrm{~km} \mathrm{ASL}$; in August up to $10 \mathrm{~km} \mathrm{ASL}$; in September up to $6.0 \mathrm{~km}$ ASL; and in October up to $7.0 \mathrm{~km}$ ASL. Video and visual data from KVERT reported ash clouds in January-October up to $6.5 \mathrm{~km}$ ASL and steam-gas columns up to $4.5 \mathrm{~km}$ ASL. Rather often ash plumes originated from glowing avalanches resulting from the collapse of frontal segments of squeezing fresh lava (Fig. 2b). Steam-gas (possibly with some ash) plumes stretched for distances of up to $10 \mathrm{~km}$ in different directions from the volcano. At night the glow of the dome and collapse of incandescent avalanches were observed almost constantly. Dome activity somewhat increased in November with ash plumes reaching $8.5 \mathrm{~km}$ ASL. Satellite data demonstrated ash and steam-gas plumes extending to distances of up to $400 \mathrm{~km}$ in different directions from the volcano (Fig. 3a). In April-July the ash plumes were not longer than $110 \mathrm{~km}$; in August-September and November the ash and steam-gas plumes extended for $90-150 \mathrm{~km}$ and in October, up to $250 \mathrm{~km}$ from the volcano. The directions of plumes also differed (Fig. 3a). Seismological data [8] detected ash ejections up to $6.0 \mathrm{~km} \mathrm{ASL}$ at the beginning and end of December. At that time visual 


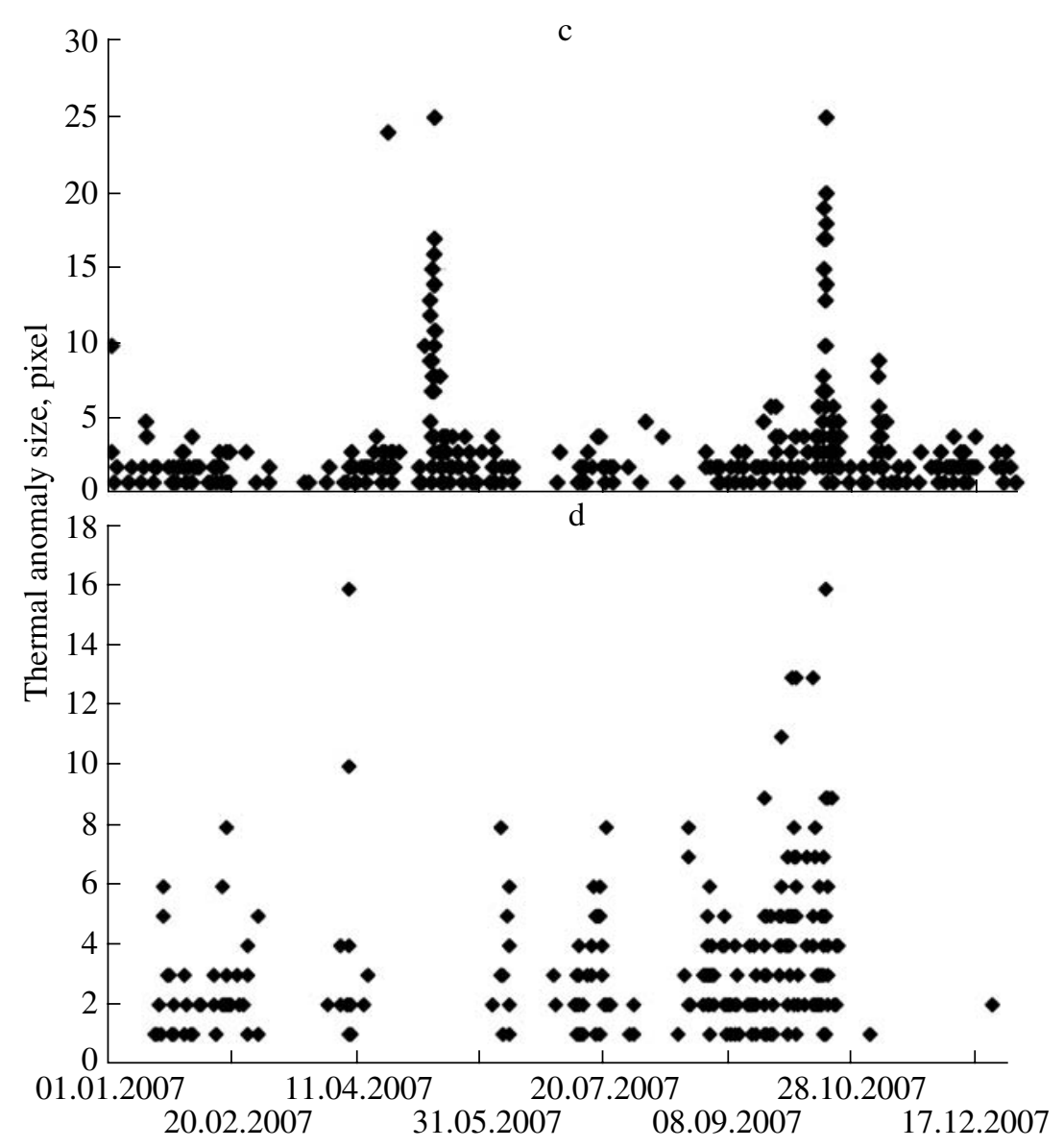

Fig. 1. Contd.

observation showed moderate steam-gas activity on the volcanic dome and ash ejections up to $6.0 \mathrm{~km}$ ASL. Satellite information recorded ash and steam-gas plumes as long as $120 \mathrm{~km}$ in different directions from the volcano.

On December 18, 2007 at 00:30 UTC an extraordinary issue of the KVERT Information Release published the warning: "Based on seismic data, the activity of Shiveluch Volcano has increased since December 10. The number of shallow volcanic earthquakes increased from 70 to 390 from December 10 to 17 . The danger of the volcano for aviation has increased."

From 19:30 UTC on December 19 to 23:50 UTC on December 20 the ACC for the Shiveluch Volcano was red because seismological data from 06:23 to 14:45 UTC of December 18 and from 08:00 to 11:00 UTC of December 19 recorded two episodes of strong explosive activity, with ash clouds rising up to 6.5 and $8.7 \mathrm{~km} \mathrm{ASL}$, respectively. The height of ash clouds estimated by the KBGS on the basis of seismological information, approximately corresponded to values given by KVERT staff using other methods: according to meteorological data (atmospheric temperature profile) on December 18 the height of the ash clouds was about $6 \mathrm{~km}$ ASL; the PUFF model (of the AVO) estimated ash plume movement at heights of 6.0$8.0 \mathrm{~km}$ ASL on December 19. Satellite data from AVO, Tokyo VAAC and KVERT showed that ash plumes extended for $130 \mathrm{~km}$ to the west on December 18, and for more than $330 \mathrm{~km}$, at first to the northwest, then to the southwest of the volcano during December 19-20. Visual observations on December 18 recorded pyroclastic flow deposits at a distance of 5-6 km from the dome to the flow's front. On December 18 from approximately 19:00 to 23:00 UTC an ashfall took place at the Klyuchi settlement. In the area of the Levinson-Lessing Kamchatka Volcanological Station about $4.2 \mathrm{~g} / \mathrm{m}^{2}$ of grey ash fell. Low cloudiness hampered visual observations of the volcano. Seismological data recorded several small explosion events accompanied by ash ejection up to $4.0 \mathrm{~km} \mathrm{ASL}$ on December 20 and 24. These might be small glowing avalanches resulting from the collapse of lava dome blocks that were unstable after strong explosive events. From December 23 to 24 steam-gas plumes were observed visually moving to the east and northeast of the volcano. After the weather improved, two thermal anomalies in the area of the volcano lava dome and the pyroclastic flow could be seen for a long time in space imagery. Due to decreasing vol- 

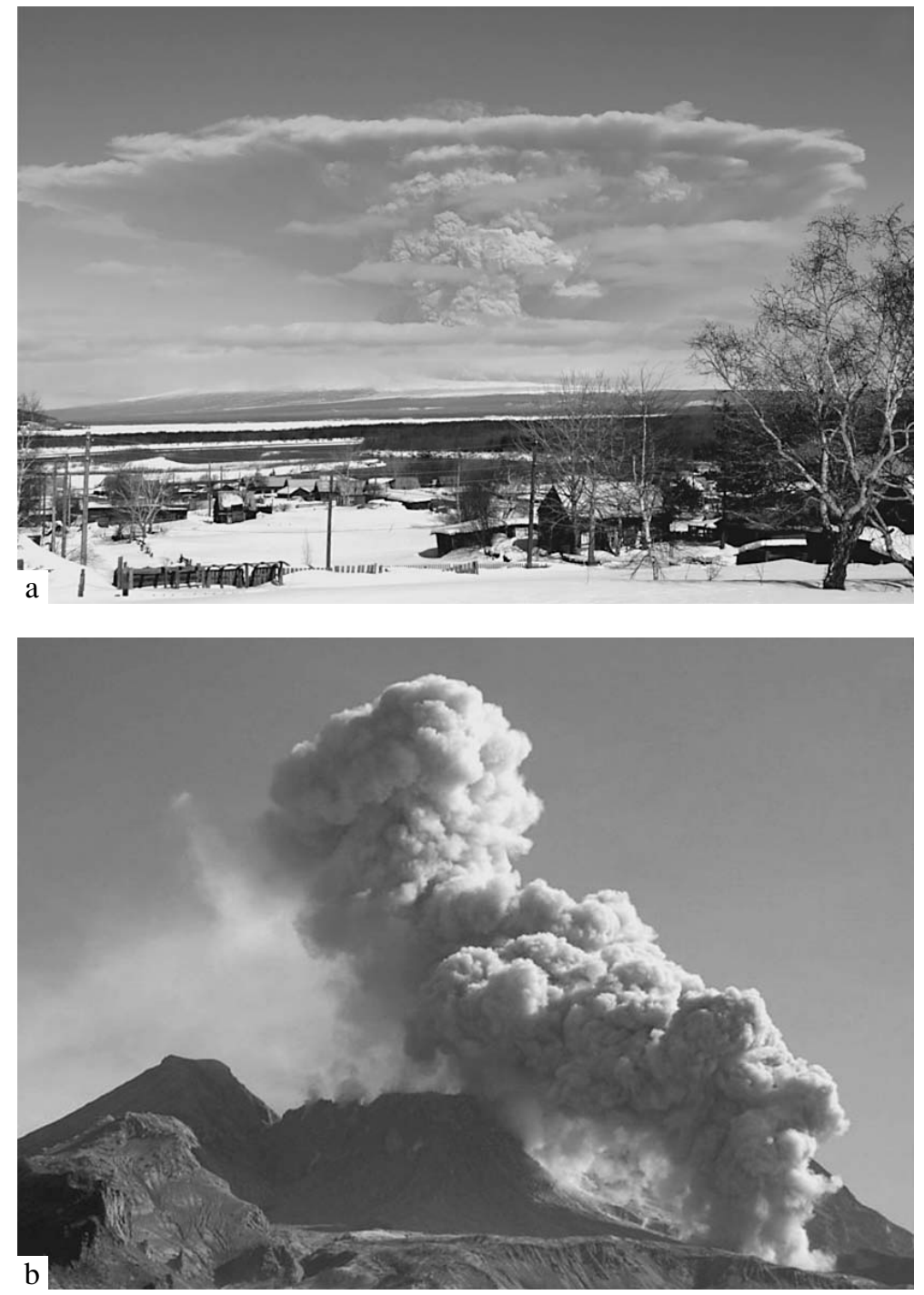

Fig. 2. (a) Explosive event on Shiveluch Volcano on March 29, 2007; photo by Yu.V. Demyanchuk. (b) Glowing avalanche on the slope of lava dome of Shiveluch Volcano on July 10, 2007; photo by N.V. Gorbach.

canic activity, the ACC was changed from red to orange on December 20 and remained at that level to the end of the year.

The volcano was visible for observations on $51 \%$ of the days from January 1 to December 31, 2007. It was visible more often in February and April, at 64 and 77\% respectively, and less visible in March and August, at 32 and $29 \%$ of the days respectively. The largest extension of ash plumes was noted in the eastern $(567 \mathrm{~km})$, southeastern $(400 \mathrm{~km})$ and northeastern $(250 \mathrm{~km})$ directions from the volcano; most often ash plumes traveled to the southeast and east from the volcano (Fig. 3a), therefore a real volcanic hazard existed in the eastern sector of the Shiveluch Volcano for international flights, and for low-flying aircraft in all the directions in the volcano area.

Slow squeezing of the magma and consequently lava dome growth is continuing at the present time
(2007-2008). Steam-gas emissions with different ash admixtures, collapse of separate blocks from the dome's top, and avalanches on the slopes with ash clouds rising up to 4-6 km ASL are observed from time to time. If magma reaches the ground surface, separate ash explosions rise up to 10-12 km ASL. With the mass of the lava dome growth explosive forms of eruption become stronger and the volcanic hazard for aviation increases.

Klyuchevskoi Volcano $\left(56^{\circ} 03^{\prime} \mathrm{N}, 160^{\circ} 39^{\prime}\right.$ E, elevation $4750 \mathrm{~m}$ ) is the highest active volcano in Eurasia and one of the most productive volcanoes of the world. Since December 18, 2006, when a weak thermal anomaly appeared at the crater on top of the volcano indicating a possible new eruption, its ACC has been yellow. In January and up to the middle of February fumarole activity was observed, with a steam-gas column rising up to 50-500 m above the crater. Since January 5, 2007 

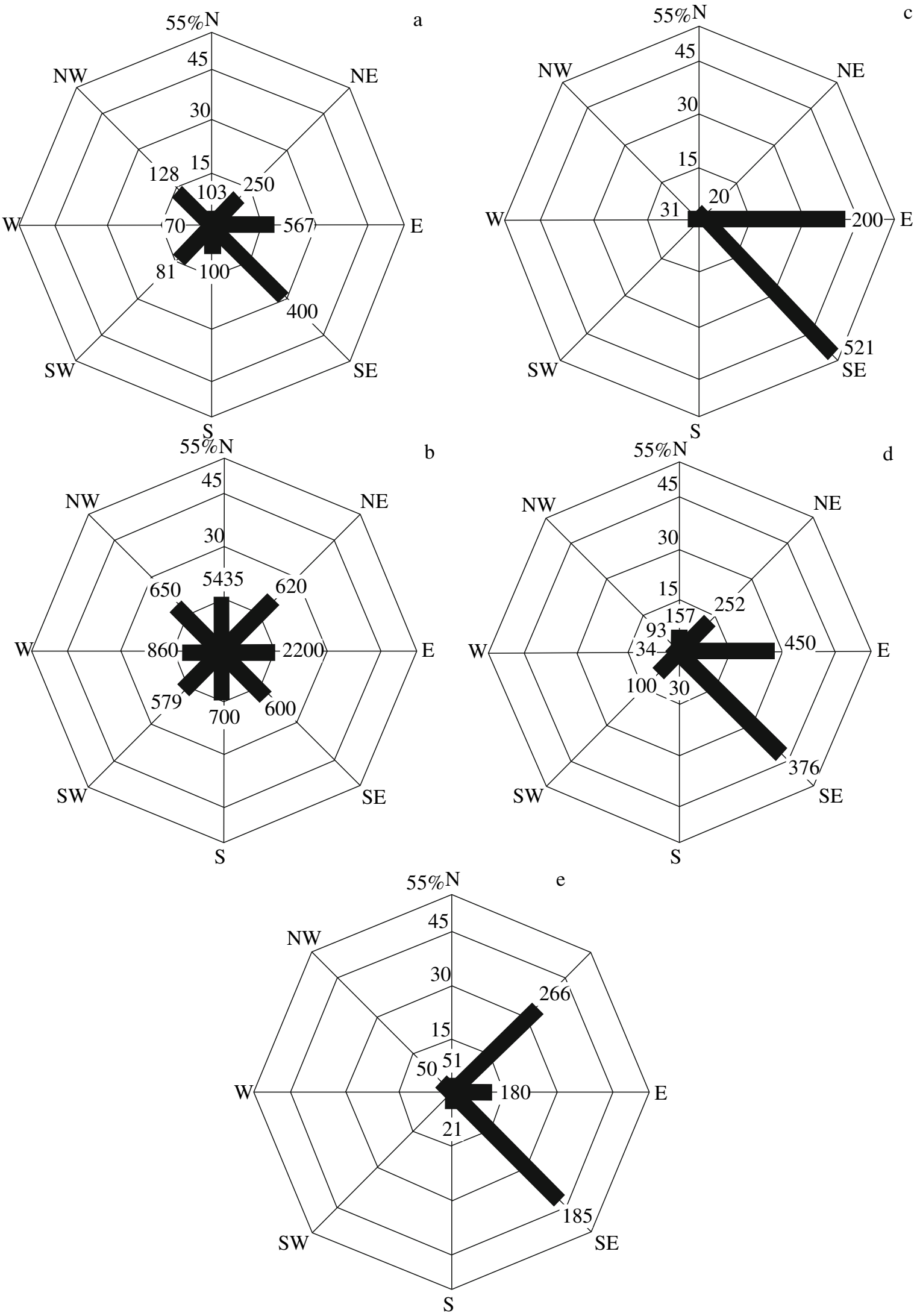

Fig. 3. Frequency of drift directions (\%) and maximum length $(\mathrm{km})$ of ash plumes from volcanoes: (a) Shiveluch (260 plumes), (b) Klyuchevskoi (867), (c) Bezymyannyi (33), (d) Karymskii (137), and (e) Chikurachki (45) in 2007. Processing of the satellite data of the KVERT IVS and the AVO was carried out by A.A. Nuzhdaev. 
a thermal anomaly with a size of $1-8$ pixels has been recorded constantly (Fig. 1b).

Strombolian activity of the volcano was first observed visually on the 15th of February, indicating the start of an explosive strombolian-vulcanian explosive eruption. Due to real ash hazard on that day the ACC was changed to orange and remained largely at this level until July 27.

Based on the data of the KBGS, from the January 1 to February 14, 2007, about 2-12 volcanic earthquakes were recorded daily with $\mathrm{M}_{l}>1.2$ at a depth of $30 \mathrm{~km}$ : http://emsd.iks.ru/ ssl/monitoring/main/htm (here and below seismological data were taken from: (a) the Northern Group of Volcanoes data base (http:// data.emsd.iks.ru/klyquake/index.htm) - for the number of volcanic earthquakes; (b) the Tsirk (Circus) seismic station situated $9.5 \mathrm{~km}$ from the volcano- the series of low-frequency events and volcanic tremors). In the period from February 15 to 28 the number of volcanic earthquakes increased to 3-60 events daily due to the beginning and progress of terminal volcanic eruption. From January 1 to March 14 the number of shallow volcanic earthquakes also increased to 200-600 events daily (Fig. 4a). In addition to separate volcanic earthquakes, from January 1 to March 7 series (up to 10100 daily) of low-frequency events were recorded; from March 8 to 14 their number increased up to 50250 daily (Fig. 4b). Volcanic tremor was noted first on January 19 (Fig. 4c). At the beginning it was intermittent, but from March 10 to August 22 and during October 3-29 it was continuous.

From February 15 to April 23 strombolian activity of the volcano was observed; volcanic bombs were thrown up to $300-500 \mathrm{~m}$ above the crater's rim (up to $5.2 \mathrm{~km}$ ASL). In March ejections from the crater took place sometimes every 1-10 minutes. On March 28 effusive activity commenced with an outflow of lava along the Krestovskii channel on the west-northwest slope. At the end of March the size of the thermal anomaly increased up to 17 pixels. In March satellite data showed steam-gas plumes with minor ash propagating for 20-45 km northeast and northwest of the volcano (Fig. 3b). On February 24-25 in Klyuchi settlement snowfall occurred jointly with ashfall.

At the end of March the number of shallow earthquakes gradually decreased to 100-300 events daily. On April 12 earthquakes recorded at depths of $30 \mathrm{~km}$ decreased to 1-3 events daily, since April 13 such earthquakes were not noted.

On April 9 a second lava flow appeared to the east of Krestovskii channel. Volcanic activity increased on April 15 and 17-18. During these days, steam-gas columns with a minor ash admixture rose up to 6.3 and $7.2 \mathrm{~km}$ ASL, respectively. On April 24 lava flows descended to $3.5 \mathrm{~km}$ ASL, and mud flows advanced from the lava flow fronts down to $2.0 \mathrm{~km}$ ASL. From April 24 to 25 phreatic explosions often occurred at the contact between lava flows and ice cover with ash ejected up to $8.5 \mathrm{~km} \mathrm{ASL} \mathrm{(Fig} \mathrm{5a).} \mathrm{According} \mathrm{to} \mathrm{satel-}$ lite information for April, ash plumes stretched to the northeast and northwest of the volcano for $220 \mathrm{~km}$ (Fig. 3b). Ashfall took place in the Klyuchi settlement on May 3-4. Here, during May, one could hear sounds like rolls of thunder when strong explosions occurred on the volcano. On May 9 a 100 meter wide mud flow advanced along the Kirgurich River stream channel (13 km east of Klyuchi settlement). On May 11-12 ash clouds rose up to 9-10 km ASL and ashfall occurred in the settlement. Ashfalls also took place on May 16-18. In the area of former Klyuchi airport a mud flow arrived from the front of the lava flow on the north-northeastern slope of the volcano. The mud flow blocked the Krivaya channel, but on May 17 no water was present in the latter. Yu.V. Demyanchuk observed that on May 23 the height of the cinder cone above the crater's rim was about $70 \mathrm{~m}$; the base diameter was $570 \mathrm{~m}$, and the crater diameter was $170 \mathrm{~m}$.

From May 30 to June 21 the explosive activity of the volcano decreased somewhat and the height of the ash columns didn't exceed $7.0 \mathrm{~km}$ ASL. A new lava flow was observed on May 31 on the eastern slope of the volcano; on the same day lava spouted from two vents (Fig. 5b). Strong phreatic explosions were observed at the front of the lava flow at an elevation of about $3.9 \mathrm{~km}$ ASL. Based on satellite data, colleagues from the AVO estimated the following parameters of the lava flow on the southeastern slope: a length of $2 \mathrm{~km}$ and a width of $100 \mathrm{~m}$. Owing to the appearance of a third lava flow, on June 2 the thermal anomaly enlarged to 55 pixels composed of the thermal anomaly in the summit crater and three lava flows (Fig. 1b, 6a). A strong explosion took place on June 2 on the northern rim of the crater, close to the cinder cone.

From May 16 to June 2 and from June 19 to July 4 very intensive explosive activity was observed, with ash plumes rising up to $10-12 \mathrm{~km}$ ASL, ash plumes stretched for more than $5400 \mathrm{~km}$ primarily in the eastern directions from the volcano, consequently the ACC was red (Fig. 5c). At 22:00 UTC on June 19 volcanic tremor amplitude reached $83 \mu \mathrm{m} / \mathrm{s}$, an ash plume rose up to $12 \mathrm{~km}$ ASL. On June 17-18 in Klyuchi and June 19-21 in Kozyrevsk settlements rains with ashfalls occurred. In Klyuchi settlement one could hear explosion sounds from the volcano. According to information of the Meteorological Center of the Elizovo Airport for June 20, aircraft pilots recorded ash clouds at $7.5 \mathrm{~km}$ ASL. On June 20 an ash plume traveled over Elizovo and Petropavlovsk-Kamchatskii (Fig. 6b). Though no ashfalls were noted in these towns, the ash hazard for aviation was real. Based on satellite information, in June ash plumes traveled at elevations up to $9.5 \mathrm{~km}$ ASL for a distance of 400-900 km in different directions from the volcano. On June 29 an ash plume at an elevation of more than $9.0 \mathrm{~km}$ stretched to the east for $300 \mathrm{~km}$, propagating farther for $2200 \mathrm{~km}$ and reaching the Aleutian Islands. The most extended ash plumes 

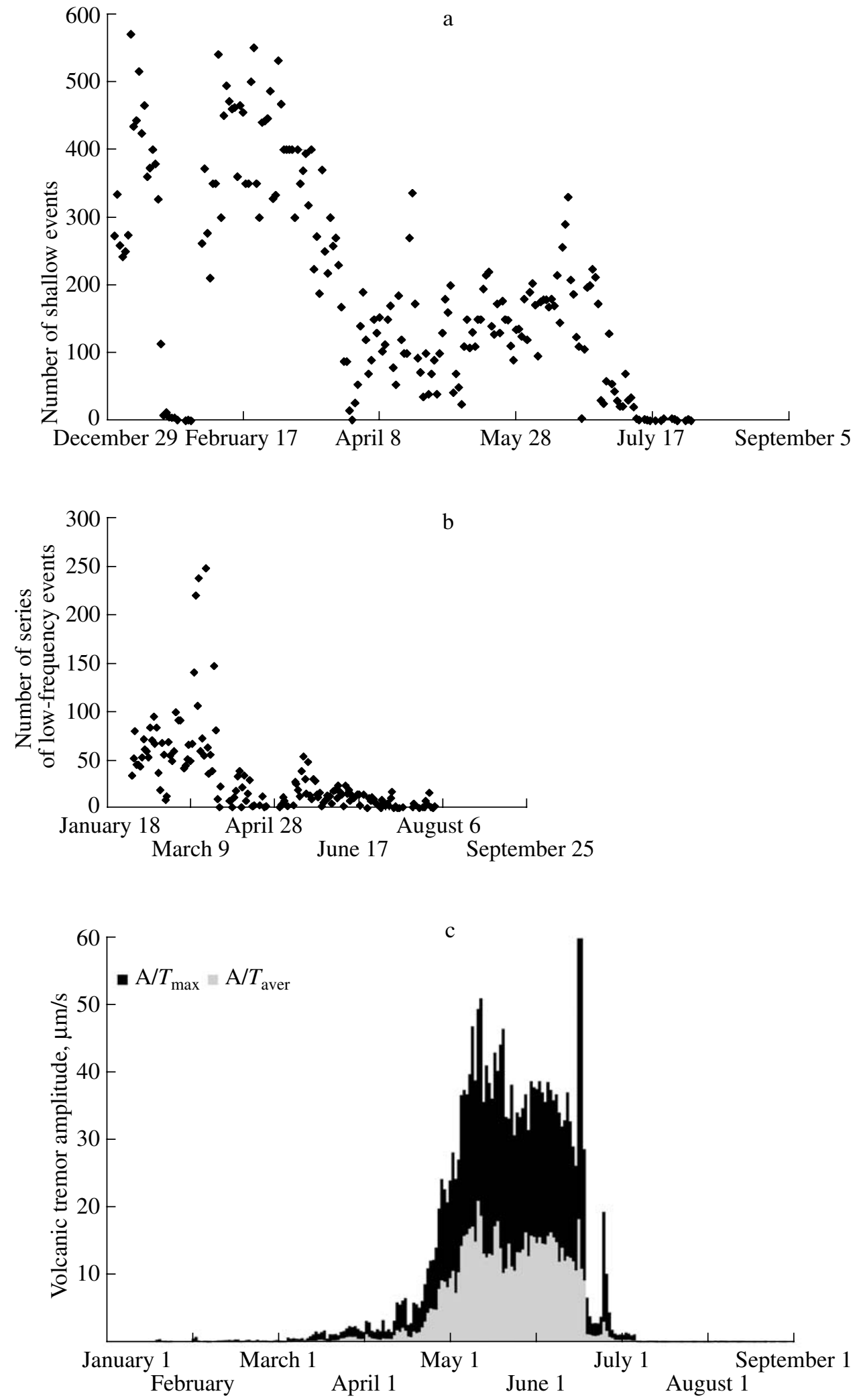

Fig. 4. Variation in numbers of shallow volcanic earthquakes (a), series of low-frequency events (b), and maximum and average amplitude of volcanic tremor (c) during eruption of Klyuchevskoi Volcano in 2007, based on the data of the KBGS: http://emsd.iks.ru/ ssl/monitoring/main.htm. 

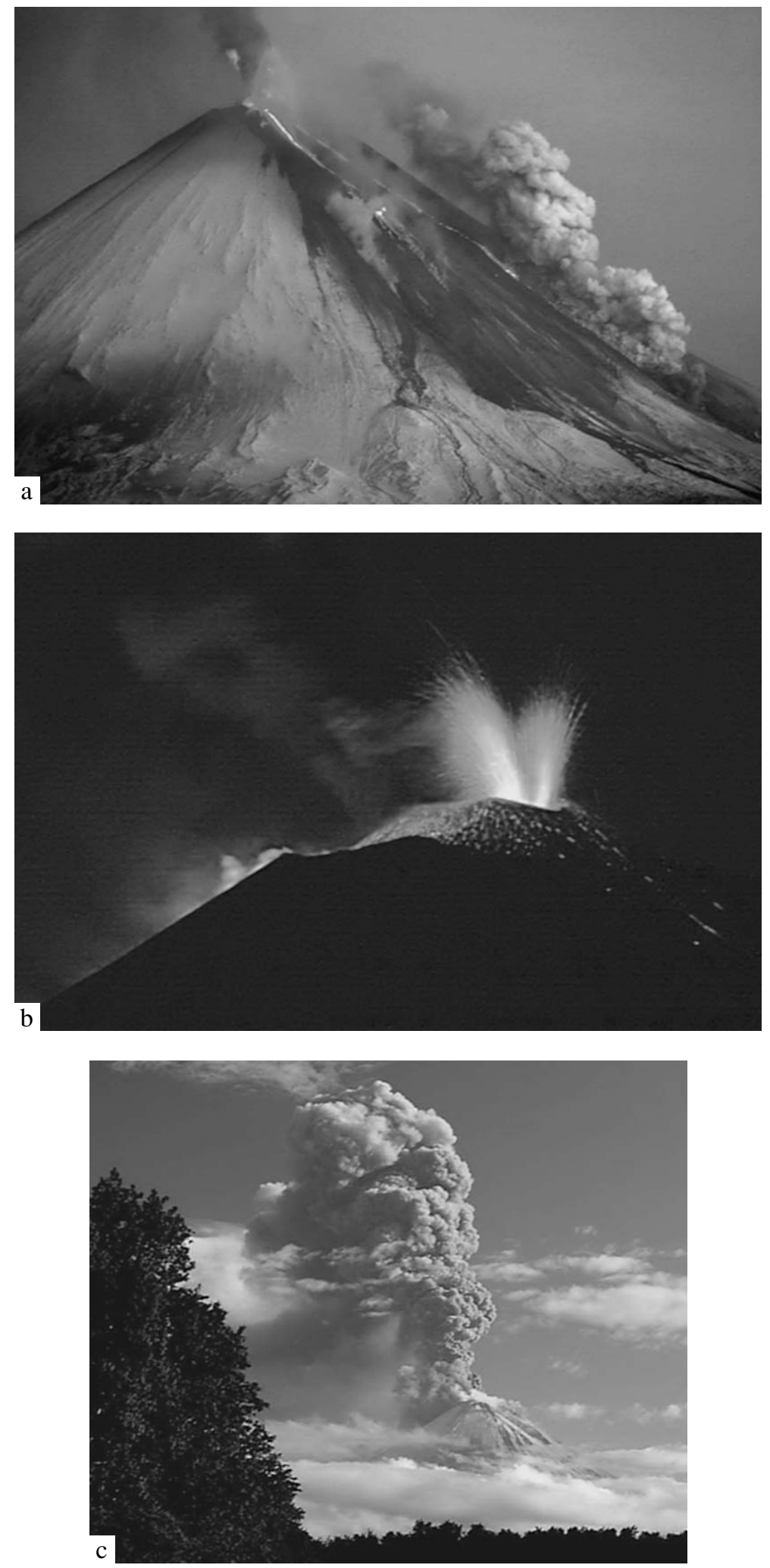

Fig. 5. Explosive-effusive eruption of Klyuchevskoi Volcano as of May 27 (a), May 31 (b), and June 29,2007 (c). Photo by Yu.V. Demyanchuk. 

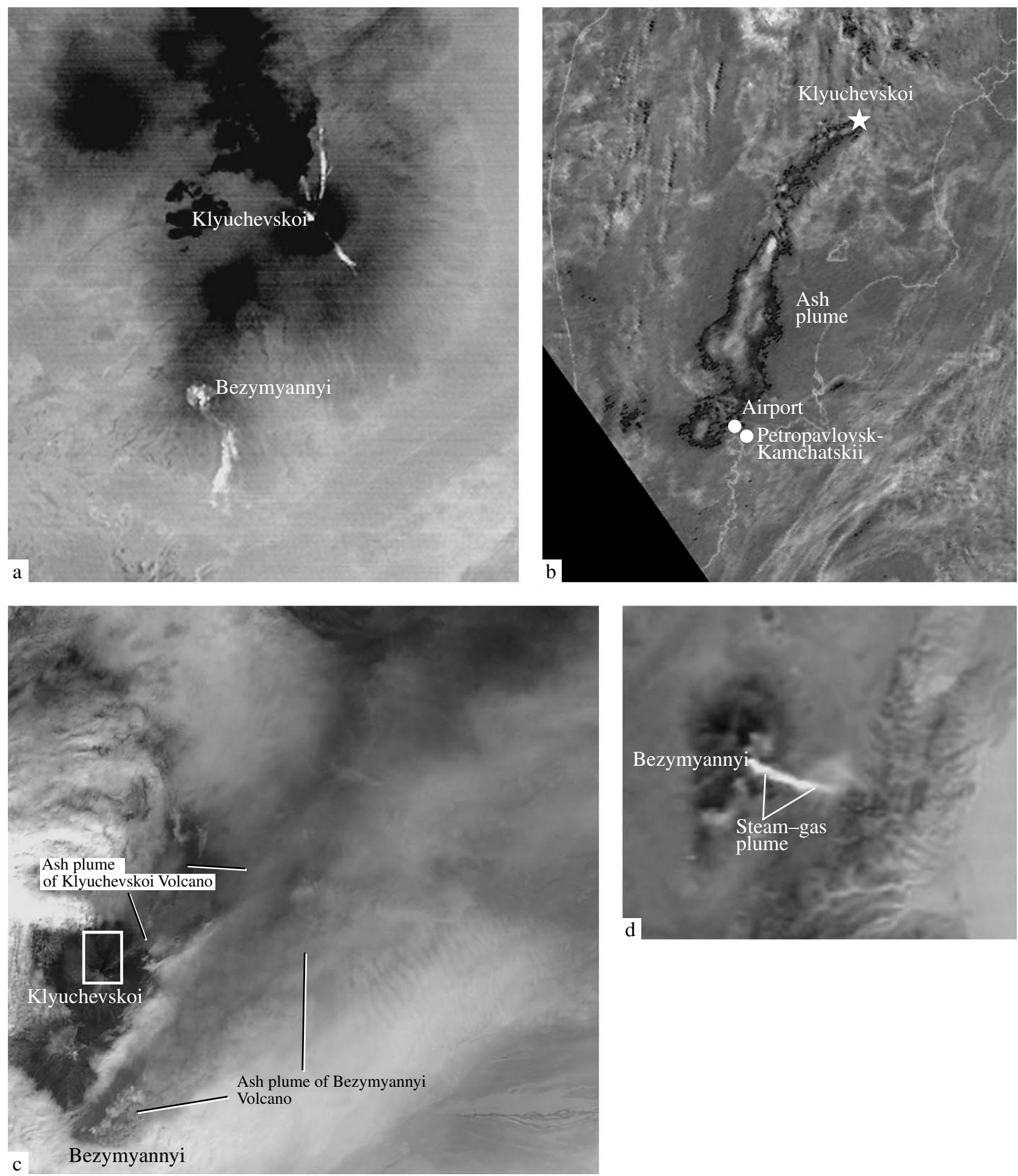

Fig. 6. Thermal anomalies in the area of Klyuchevskoi and Bezymyannyi volcanoes on an ASTER satellite image at 11:02 UTC on July 7, 2007 (a); ash plume from Klyuchevskoi Volcano in the areas of Petropavlovsk-Kamchatskii and airport at 04:30 UTC on June 20, 2007 on an image NOAA-12, AVHRR (4m5), courtesy the AVO (USA) (b); the moment of simultaneous eruptions of Klyuchevskoi and Bezymyannyi volcanoes on an ASTER VNIR satellite image at 00:38 UTC on May 12, 2007, courtesy M. Ramsey, USA (c); bright steam-gas plume from Bezymyannyi Volcano at 23:59 UTC on November 9, 2007 on an image of TERRA MODIS, courtesy ROSGEOLFOND, MNR RF (d). 
during the eruption (5435 $\mathrm{km}$ to the north) were noted on June 28, 2007 (Fig. 3b).

The Ozone Monitoring Instrument (OMI) system mounted on board the AURA satellite (NASA) was used in 2007 to monitor the $\mathrm{SO}_{2}$ atmospheric concentration in ash and aerosol plumes during eruption of Klyuchevskoi Volcano (http://disc.sci.gsfc.nasa.gov/ Aura/). At the beginning of volcanic activization (February-March 2007) the $\mathrm{SO}_{2}$ concentrations around it were too low to be detected by $\mathrm{OMI} \mathrm{SO}_{2}$. During that period visual observations reported moderate strombolian and intense steam-gas activity. Only toward April 20, when lava outflows and ash ejections were already occurring, higher $\mathrm{SO}_{2}$ concentrations were recorded over Kamchatka. For example, on June 22 an ash-aerosol plume spread out over central Kamchatka in an area of $146825 \mathrm{~km}^{2}$, and it included about 6000 tons of $\mathrm{SO}_{2}$. According to the data of Simon Carn (Simon Carn, OMI-team, NASA's Aura satellite), in the course of the active eruption phase of Klyuchevskoi Volcano more than 120000 tons of sulfur dioxide were put into the atmosphere.

For the entire period of the volcano's eruption 867 ash plumes were detected. Their greatest lengths varied from 580 to $5435 \mathrm{~km}$ in different directions, but the frequency of occurrence of all the directions was approximately the same (Fig 3b), although most of the ash plumes extended to the northeast, southeast and northwest of the volcano. This means that at the time of the Klyuchevskoi Volcano eruptions in 2007 a real hazard for international and low-flying aircraft existed in all directions from the volcano.

Gradually volcanic activity diminished. In the first half of July ash ejections up to 5-7 km ASL were reported. The last steam-gas plumes with an ash admixture were recorded on July 15-17. Based on KBGS data, on July 10 the volcanic tremor dropped to the background level, toward August 1 the number of series of low-frequency events decreased to 1-20, and from August 2 on they were not noted. From June 28 to the middle of July the number of shallow earthquakes sharply dropped to 20-130, then to 1-4 cases per day. After August 1 only small shallow earthquakes were recorded in the volcanic edifice. Because of the gradual cessation of volcanic activity its ACC was changed on July 20 from orange to yellow and on August 17 to green. Thus, the terminal eruption of the Klyuchevskoi Volcano in 2007 continued for about 5 months.

From the beginning of October to the middle of December weak shallow earthquakes were again recorded on Klyuchevskoi Volcano. The KBGS reported about 75 events in a $7 \mathrm{~km}$ radius from the crater in a depth range from the crater surface to $35 \mathrm{~km}$ below sea level. In this period weak volcanic tremor of much smaller amplitude was also recorded. The tremor maximum amplitude $(83.9 \mu \mathrm{m} / \mathrm{s})$ was noted at the time of strongest explosive events when ash columns rose to $12 \mathrm{~km}$ ASL. In September-December volcanic tremor amplitude didn't exceed $0.14 \mu \mathrm{m} / \mathrm{s}$, possibly resulting from some sagging of the magmatic column in the volcanic edifice and the cinder cone on its top. Up to the end of the year weak fumarole activity was observed occasionally and steam-gas plumes rose to $50-500 \mathrm{~m}$ above the crater. In terms of weather conditions the volcano was visible $56 \%$ of the days of the year: the longest period was in November ( $77 \%$ of the days) and it was less visible in August (19\% of the days).

Bezymyannyi Volcano $\left(55^{\circ} 58^{\prime} \mathrm{N}, 160^{\circ} 36^{\prime}\right.$ E, elevation $2882 \mathrm{~m}$ ) situated in the central part of the Klyuchevskoi group of volcanoes is one of the most active Kamchatka volcanoes. The ACC due to this volcano remained mainly yellow during 2007, with the exception of periods of strong explosive eruptions: in May 10-17 (orange ACC) and in October 14-16 (red ACC). Due to some diminution of volcanic activity, in October 16-20 and in November 10-22, in connection with possibility of recurrent explosive eruption, the ACC was orange.

According to KBGS data, in January in the volcanic area rare volcanic earthquakes continued and a series of low-frequency events related to gradual "steadying" of the Bezymyannyi Volcano after its explosive eruption in December 24, 2006 (here and below seismological data are from the Zelenaya seismic station $13.5 \mathrm{~km}$ away from the volcano: http://emsd.iks.ru/ ssl/monitoring/main.htm). During the month it recorded five events in the depth range from -1.5 to $5.9 \mathrm{~km}$ relative to sea level (with the last one on January 21), eight shallow events (with the last one occurring on January 31), and twelve series of events (with the last one occurring on January 27). A thermal anomaly in the lava dome area was sometimes noted, probably caused by squeezing of viscous lava flow onto its slope after the December paroxysm. In January-April a KVERT release reported: "The volcanic activity decreased, but the lava dome continues to grow. Near the volcano there is a danger for low-flying aircraft due to small ash and aerosol plumes." In February-March until the middle of April the seismicity of the volcano was largely below the level of recording; only for two days in February and March was it at the background level. From April 14, due to strong explosive eruption of Klyuchevskoi Volcano the KVERT release reported: "Correct seismic monitoring of the volcano is not possible because of the high seismicity of the Klyuchevskoi Volcano." However, shallow earthquakes with magnitude 2.2 and 1.9 were recorded by the KBGS on April 21 and 24, respectively; on May 10 one more shallow earthquake with magnitude 2.5 occurred. From January 1 to 10 the volcano showed weak or moderate fumarole activity.

On May 5 and 8, hunters from Klyuchi and Sukhaya Khapitsa saw mud flows in the Sukhaya Khapitsa River (the area of Bezymyannyi Volcano). Based on the report by KVERT staff from the IVS of a sharp temperature rise and thermal anomaly on May 9-10 (Fig 1 c), on May 10 at 22:55 UTC the KVERT Information 
Release 16-07 published an orange ACC and indicated that "ash explosions up to $10 \mathrm{~km}$ ASL may occur on the volcano at any time."

The strong eruption of Klyuchevskoi Volcano at that time hampered the tracing of the seismic activity of the Bezymyannyi Volcano by the KBGS and, consequently, prediction of the eruption of the latter. The sequence of events of Bezymyannyi Volcano eruption was restored by O.A. Girina (KVERT) using indirect data and published on May 13, 2007 in KVERT Information Release 17-07. This interpretation was later supported by examination of the ASTER space image (AVO).

Major events of the Vulcanian type took place on May 11 in the interval of 14:30-15:00 UTC (KBGS data from the seismic station in Kozyrevsk settlement). In June 2007 the duration of the volcano eruption was refined by the staff of the KBGS using data from the Zelenaya seismic station. According to S.L. Senyukov (personal communication), an explosive eruption took place on May 11 at about 14:45-15:10 UTC, when a seismic event with maximum value of $\mathrm{A} / \mathrm{T}=15.4 \mu \mathrm{m} / \mathrm{s}$ was recorded.

Space imagery data showed that ash ejection continued on Bezymyannyi Volcano also after the most active seismic phase: at 00:38 UTC on May 12, a vigorous ash plume stretched to the northeast from Bezymyannyi Volcano, and from Klyuchevskoi Volcano a thin ash plume was traced to the east-northeast (Fig. 6c). At a distance of 20-30 km from the volcanoes the plumes crossed and farther away they formed a single vigorous cloud in which ashes from both volcanoes were mixed well. On May 11-12 space images showed different directions of the ash plumes and clouds traveling, owing to strong cyclonic activity in the area of northern volcano group. Visual observations of Bezymyannyi Volcano from Kozyrevsk settlement at 22:30 UTC on May 11 recorded one of the glowing avalanches that are common in explosive eruptions of the volcano. Ash rose up to $4 \mathrm{~km} \mathrm{ASL}$

On May 11, from 16:00 to 22:00 UTC in the Klyuchi settlement ashfall occurred with an ash layer about $0.3-0.4 \mathrm{~cm}$ thick consisting largely of fine grey particles of Bezymyannyi Volcano product composition. An admixture of coarse $(0.5-1.0 \mathrm{~mm})$ dark-colored particles was also noted; those originated from the Klyuchevskoi Volcano, eruption of which continued. An ash plume extended for more than $100 \mathrm{~km}$ from Bezymyannyi Volcano (Fig 3c). A bright, large (11 pixels) NW-SE trending thermal anomaly on the NOAA-18 image at 14:29 UTC on May 12 indicated the fresh hot deposits of a pyroclastic flow. On an ASTER image of July 7, 2007 the pyroclastic flow is well depicted by a thermal anomaly (Fig 6a). Powerful mud flows were again observed in Sukhaya Khapitsa River valley on May 17: a 200-m-wide flow moved along the stream channel above the snow cover. Mud flows probably began to form from May 5 or somewhat earlier due to activation of Bezymyannyi Volcano, commencement of the extrusive process and collapse resulting in glowing avalanches. Powerful mud flows still moving even a week after eruption of the volcano were probably related to the formation of an incandescent pyroclastic flow on the volcano slope and later to its deposits. Due to the diminishing activity of the volcano on May 17, its ACC was changed to yellow and remained at that level until October 14.

After termination of the Klyuchevskoi Volcano eruption, the seismicity of the Bezymyannyi Volcano could be recorded by KBGS seismic stations with almost no interference. Until the end of September in the area of Bezymyannyi Volcano shallow volcanic earthquakes were recorded almost every day. For example, six events were recorded each day on July 17 and 22 , and eight on July 19 . There were volcanic earthquakes in the depth range from -1.9 to $3.6 \mathrm{~km}$ relative to sea level. Earthquake frequency significantly decreased in August and remained at that level in September. For example, in July about 50 shallow events were recorded, while in August and September about 24 occurred each month. On September 24 and 25, however, four and six series of shallow events, respectively, were recorded, possibly resulting from the collapse of glowing avalanches or ash ejections. A 35-kmlong ash plume was seen on a space image of September 25 stretching to the east of the volcano. In addition, the thermal anomaly above the lava dome grew in extent and intensity (Fig. 1c). Based on these data, the ACC remained yellow. On September 28 KVERT reported: "The volcanic activity increased. In the next few weeks explosive eruption of the volcano is possible, with an ash cloud rising up to $10 \mathrm{~km}$ ASL. The volcanic area remains dangerous for international and lowflying aircraft due to possible ash and aerosol plumes." Next week, on October 1 and 3-4, upon a background of relatively low seismic and fumarole activity of the volcano, the intensity of the thermal anomaly in the lava dome area increased and on October 6, 8, and 11 the anomaly was very bright. One series of low-frequency events was recorded each day on October 3 and 10. On October 5 and 12, the KVERT published the warning: "The volcanic activity is growing. In the several next weeks an explosive eruption may occur with an ash cloud rising up to $10 \mathrm{~km}$ ASL The volcanic area remains dangerous for international and low-flying aircraft due to possible ash and aerosol plumes."

On October 14 at 16:48 and 18:05 UTC the KVERT staff received a message from the Tokyo VAAC that ash plumes were stretching from Bezymyannyi Volcano. On October 14 at 22:15 UTC the ACC was changed to red with the note "The activity of the volcano is dangerous at present for low-flying and international aircraft. Possibly this is the precursory process before a stronger eruption of Bezymyannyi Volcano."

In fact, the eruption was unusually prolonged. Based on seismological data from the KBGS an explo- 
sive eruption began on October 14 at about 14:27 UTC and continued with interruptions until 14:00 UTC of October 15 . The maximum velocity of $S$-wave displacement $(\mathrm{A} / T)$ during the eruption reached $1.6 \mu \mathrm{m} / \mathrm{s}$. On October 14 and 15, 8 and 18 series of low-frequency events were recorded respectively, as well as 117 and 209 shallow earthquakes. Volcanic tremor continued for about half an hour on October 14 and 10 hours on October 15. Visual observations recorded an ash column up to 9-10 km ASL stretching to the southeast of the volcano. On October 14-15 satellite information revealed a bright thermal anomaly with a size of 25 pixels (Fig. 1c). On October 14-16 ash plumes extended primarily to the east and southeast of the volcano at elevation of $10 \mathrm{~km}$ ASL on October 14 and at 7-8 km ASL on October 15-16. Separate ash clouds were noted at a distance of more than $1000 \mathrm{~km}$ from Bezymyannyi Volcano. On October 16 at 03:15 UTC the ACC was changed from red to orange with the warning: "Although no ash plumes have been observed on space imagery for several hours, such plumes are still seen above the water area of Kronotskii Bay. These plumes, as well as aerosol plumes possibly existing in the area of just erupted volcano, may be dangerous for low-flying aircraft."

Although volcanic tremor was not detected since 14:00 UTC of October 15, on October 16, 46 earthquakes were recorded. On October 17 and 18, 16 and 19 earthquakes were detected, respectively. Satellite information from the Tokyo VAAC and KVERT for October 16-18 didn't recognize ash clouds in the volcanic area, but a rather high ash presence was noted above the Pacific in the Kamchatka area. A strip of pyroclastic deposits from the volcano to the sea shore was observed on NOAA and TERRA MODIS images on October 18. A bright thermal anomaly in the volcano area was observed on October 16-18 (Fig 1c). It was probably related to outflow of viscous lava onto the dome's slope and pyroclastic flow deposits on the volcano's slope. On October 20 the ACC was changed to yellow because the volcano's seismic activity gradually diminished, no ash plumes in the volcano's vicinity were observed.

Volcanologists flying over the volcano in a helicopter on October 21 recognized pyroclastic flow deposits extending for about $5.5 \mathrm{~km}$ on the southeastern slope of the volcano (Fig 7a). On the southeastern slope of the volcano they detected a deep channel about $400 \mathrm{~m}$ long extending from the top to the somma half filled with lava flow (Fig. 7b). As much as 5-6 days had passed since the eruption, so the velocity of the outflow was estimated at about $70 \mathrm{~m} /$ day.

In November the volcano's seismic activity was at the background level. From time to time weak volcanic earthquakes occurred in the edifice, probably resulting from squeezing of viscous lava flow onto the dome's slope and the collapse of small glowing avalanches from its front. Minor fumarole activity was detected by visual observation. A weak thermal anomaly was indicated by satellite information in the dome area (Fig 1c).

On November 5 from 08:43 to 10:10 UTC the KBGS recorded seven shallow volcanic earthquakes, eight low-frequency series with $\mathrm{A} / T=10.9 \mu \mathrm{m} / \mathrm{s}$, and volcanic tremor with an amplitude of $0.36 \mu \mathrm{m} / \mathrm{s}$. A series of explosive events or collapses of frontal parts of the lava flow probably took place. Later, at 15:45 UTC and 18:07 UTC of the same day, small glowing avalanches were observed. The eruption of November 5 at 22:00 UTC was separately reported by KVERT without changing the ACC. The height of ash ejections was not known because of heavy cloudiness in the volcano area during November 1-6. Satellite information was not available at the KVERT at that time. AVO (NOAA-16) satellite data revealed a bright thermal anomaly above the volcano's dome at 17:52 UTC on November 5. On November 9 scientists flying over the volcano in a helicopter found that a collapse of the frontal parts of old lava flows formed in 1989-2001 occurred on November 5. Probably, the long-continued explosive eruption of October 14-16 and deepening of the channel under the frontal parts of the above-mentioned flows resulted in their instability, and finally in collapse. Such processes, i.e., collapse of segments of lava flows of andesite volcanoes, as well as the frontal parts of eruptive columns are accompanied by autoexplosivity phenomena, resulting in the accumulation of pyroclastic flow deposits. In the case under consideration the flow length was about $4 \mathrm{~km}$. In such cases ash clouds rise to an elevation of not more than 5-6 km ASL.

Satellite information (TERRA MODIS images) revealed a very bright $35 \mathrm{~km}$ long steam-gas plume extending to the east of the volcano at 23:59 UTC on November 9 (Russian data) (Fig 6d). Previous studies of Bezymyannyi Volcano suggested the possibility of a strong explosive eruption in the next 24 hours. The November 5 events probably increased the instability of the dome lava flows; therefore their collapse could take place in the nearest future. A bright steam-gas plume stretching up to $100 \mathrm{~km}$ to the east of the volcano was observed on space images during the next five days, on November 9-13. Similar plumes were observed before strong explosive eruptions: in 1986, for two days, and in 2002 for 18 hours before the eruptions. This time no explosive eruptions occurred or they remained unobserved. It should be noted that on November 12 the KBGS recorded nine shallow earthquakes $(\mathrm{A} / T=2.5 \mu \mathrm{m} / \mathrm{s})$ and a series of low-frequency events $(\mathrm{A} / T=1.26 \mu \mathrm{m} / \mathrm{s})$; on November 13 and 14, one series of events each day $(\mathrm{A} / T=2.26$ and $1.96 \mu \mathrm{m} / \mathrm{s}$, respectively) and one small earthquake each day; on November 15, two shallow earthquakes $(\mathrm{A} / T=1.05 \mu \mathrm{m} / \mathrm{s})$, on November 16, two series of events $(\mathrm{A} / T=2.17 \mu \mathrm{m} / \mathrm{s})$ and one small earthquake.

On November 23 the ACC was changed from orange to yellow because no reason to maintain this danger level existed. Neither bright plumes from the 

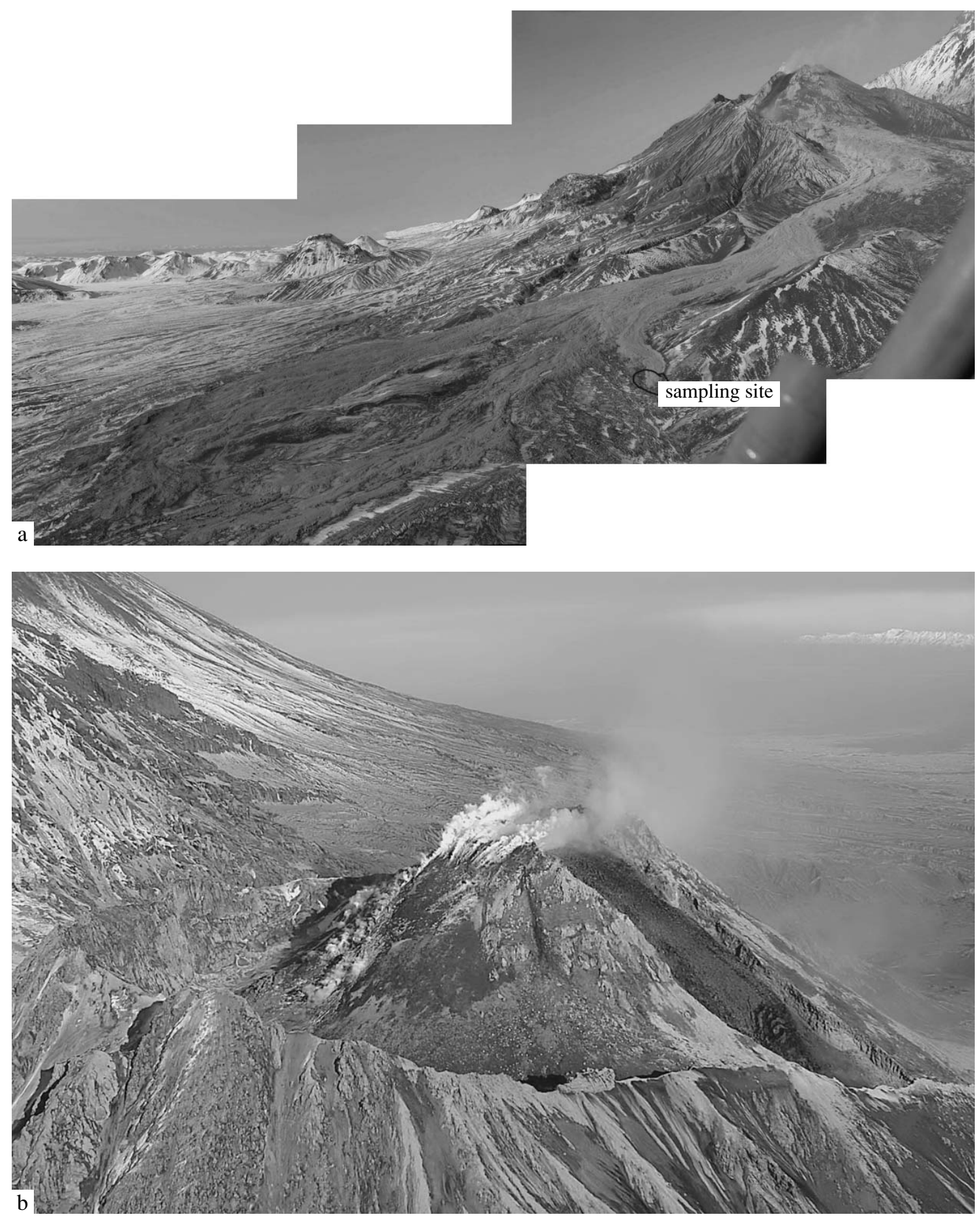

Fig. 7. Pyroclastic flow deposits on the south-southeastern slope of Bezymyannyi Volcano on October 21, 2007 (a) and fresh lava flow in a channel on the southern slope of the dome (b). Photo by Yu.V. Demyanchuk.

volcano nor a bright thermal anomaly were observed on November 14-23. Until the end of the year the volcanic seismicity was primarily at the background level, but almost daily small volcanic earthquakes were noted. If the volcano was visible, weak or moderate fumarole activity was always observed; a thermal anomaly in the volcanic area with a size of up to 5 pixels was seen on space images (Fig. 1c).

In general, according to satellite information, during explosive eruptions of Bezymyannyi Volcano in 2007 ash plumes extended primarily to the southeast and east 
of it (Fig. 3c). Ash clouds rose up to 9-10 km ASL, the length of the plumes was up to $521 \mathrm{~km}$, i.e., during eruptions of the volcano a real danger for international and low-flying aircraft existed in the eastern-southeastern sector.

In the year 2007 the volcano was visible on $38 \%$ of the days: it was visible more often in April $(60 \%$ of all days), less frequently in May (13\%). Between explosive eruptions weak fumarole activity of the dome was recorded, only on some days a steam-gas column rose up to $4.2 \mathrm{~km}$ ASL. Steam-gas plumes stretched mainly to the east, southeast, and west of the volcano.

Karymskii Volcano $\left(54^{\circ} 03^{\prime} \mathrm{N}, 159^{\circ} 27^{\prime}\right.$ E, elevation $1486 \mathrm{~m}$ ) has been in a state of explosive eruption since 1996. Due to the remoteness of the volcano from inhabited areas its condition was mainly estimated on the basis of telemetric data from the Karymskaya seismic station operated by the KBGS. In January-November 2007, as well as earlier, Vulcanian activity of the volcano was recorded, with an ash ejection up to $4.5 \mathrm{~km}$ ASL (April 21, visual observations by staff of the IVS), and up to $7.4 \mathrm{~km}$ ASL (September 8, seismological data of the KBGS). Ash plumes stretched for more than $450 \mathrm{~km}$ primarily to the southeast and east of the volcano (Fig. 3d). From January 1 to December 5 the ACC was orange and from December 6 to 31 it was yellow, due to decreasing activity of the volcano.

Based on seismological data, the activity of the volcano in 2007 was unstable with a tendency to an activity increase from mid-July to October 26 . For some days in May, November, and December the seismic station was not in operation. Seismic events, usually accompanying ash ejections to a height from 0.5 to $2.0 \mathrm{~km}$ above the crater were observed [6]. Several day long lulls in volcanic activity were sometimes recorded, after which vigorous ash ejections rising up to $7.4 \mathrm{~km}$ ASL occurred. One January 21 at 23:25 UTC and at 22:50 UTC February 5 the AMC Elizovo observed vigorous fumarole activity; a steam-gas plume at the crater level traveled to the east from the volcano. Field observations by the staffs of the IVS and KVERT in the volcanic area from April 17 to 27 recorded largely fumarole activity with a steam-gas column rising up to $2.5 \mathrm{~km}$ ASL. On April 21 a vigorous ash ejection up to $4.5 \mathrm{~km}$ ASL took place. On September 21 at 04:55 UTC the AMC Elizovo reported ash plumes up to $3.0 \mathrm{~km}$ ASL stretching to the northeast of the volcano. A research worker of the IVS, A.A. Ovsyannikov, observed strong explosions with ash rising up to $5.0 \mathrm{~km}$ ASL on October 19-24. A thermal anomaly in the volcanic area was detected on space images almost without interruption through 2007 (Fig. 1d). Registration of an anomaly with a size of 16 pixels on April 8 and October 19 was related to activization of volcanic eruptive activity those days. Ash plumes extended for more than $450 \mathrm{~km}$, mainly to the southeast and east of the volcano (Fig 3d). During all of 2007 a real ash hazard for low- flying aircraft existed in the southeastern sector of Karymskii Volcano.

At the beginning of December 2007, the volcanic activity decreased and remained at that level until the end of the year, no vigorous ash ejections occurred, but seismicity remained somewhat above the normal background. Although the ACC was changed on December 6 to yellow, the KVERT predictions of volcano danger for aircraft mentioned: "According to satellite data, ash plumes in the volcano area have not been observed during the last two months, however renewal of explosive activity of the volcano is possible. A hazard of ash plumes up to $6 \mathrm{~km}$ ASL remains. There is an ash danger for low-flying aircraft."

Avacha Volcano $\left(53^{\circ} 15^{\prime} \mathrm{N}, 158^{\circ} 51^{\prime} \mathrm{E}\right.$, elevation $2751 \mathrm{~m}$ ) was in a state of fumarole activity in 2007. The KBGS reported seismicity not above the background level; sometimes shallow earthquakes with magnitudes of up to 2.1 were recorded. A weak thermal anomaly in the crater area was detected by satellite data.

Fumarole activity was moderate. In January-April on rare occasions steam-gas columns rose up to 500$700 \mathrm{~m}$ above the crater, most of the time they were not higher than 100-300 m. During the year the permanent temperature of the fumarole on the western rim of the crater didn't exceed $200^{\circ} \mathrm{C}$. In terms of weather conditions the volcano was visible in 2007 for $62 \%$ of the time: it was visible more often in September $(90 \%$ days) less so in May (22\%).

Only one seismic station operated by the KBGS is located in the area of the Mutnovskii and Gorelyi volcanoes and it is difficult to attribute the source of seismic signals to one of the two volcanoes. The seismicity in the area remained at the background level from January 1 to July 20, while from July 21 to December 31 , 2007 it was somewhat higher. Continuous spasmodic volcanic tremor with amplitude up to $0.2-1.6 \mu \mathrm{m} / \mathrm{s}$ was recorded from April 6 to May 19 and from June 22 to December 31 , and up to $0.2 \mu \mathrm{m} / \mathrm{s}$ on the other days of the year. In terms of weather conditions in 2007 the Mutnovskii and Gorelyi volcanoes were visible on 35\% all days: more often they were visible in January (70\% of all days) and less frequently in March (10\%).

Mutnovskii Volcano $\left(52^{\circ} 27^{\prime} \mathrm{N}, 158^{\circ} 12^{\prime} \mathrm{E}\right.$, elevation $2323 \mathrm{~m}$ ). An aerosol-ash cloud was detected on the TERRA MODIS satellite image (31m32) Far East FGU NPP ROSGEOLFOND MNR RF and KVERT as of April 17, 2007 at 00:43 UTC and by workers of the KVERT and the IVS in the volcanic area (Fig. 8a). A smaller cloud was later noted on an image of the NOAA-17 AVHRR taken earlier at 23:40 UTC of April 16, 2007 [1]. Based on analysis of different data (satellite, seismic, and visual), scientific workers of the KVERT and IVS supposed that on April 16, 2007 an event with the ejection of a significant amount of aerosol, and to a lesser extent ash, material took place at the volcano. This information was transferred to the Kamchatka Branch of the Russian Expert Board (KB REB) 

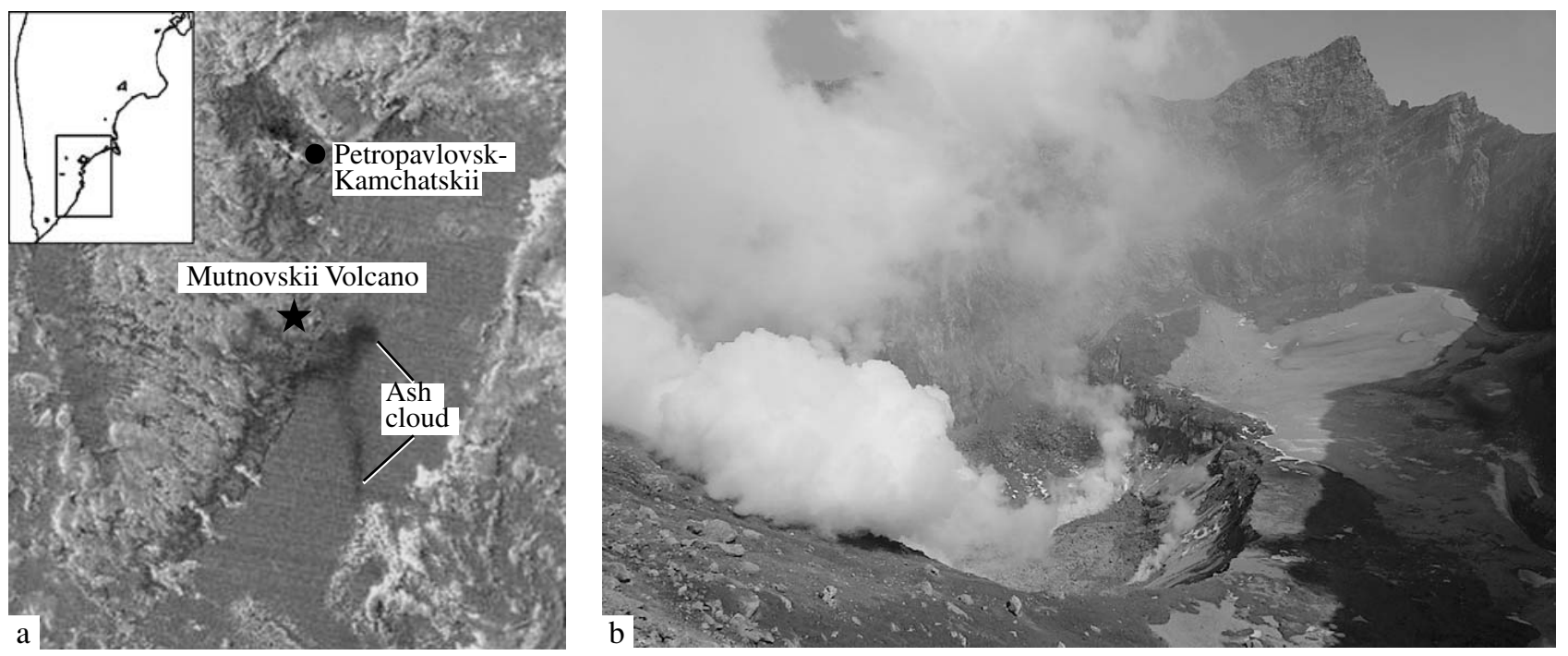

Fig. 8. Aerosol-ash plume in the area of Mutnovskii Volcano at 00:43 UTC on April 17, 2007 on a TERRA MODIS (31m32) image (ROSGEOLFOND MNR, RF); inset shows location map (a). New explosion funnel in the Active crater of Mutnovskii Volcano (b); photo taken by M.E. Zelenskii on May 25, 2007.

on April 28, 2007. A phreatic explosion probably occurred on the volcano on April 16, 2007. A large ash cloud was observed for 6 hours before it completely dissipated. On May 19, 2007 M.E. Zelenskii (of the IEM in Moscow), who visited the volcano a few days earlier, reported a thin ash coat within at least $5 \mathrm{~km}$ from the explosion centre. The KBGS informed the public that a very weak volcanic tremor began to be detected 15 days before the explosion (since April 2); the maximum tremor amplitude $(\sim 0.7 \mu \mathrm{m} / \mathrm{s})$ was recorded two days before the event; later, tremor gradually decreased. During field observations M.E. Zelenskii and D.V. Mel'nikov viewed a new explosion funnel 150-200 $\mathrm{m}$ in diameter and about $30 \mathrm{~m}$ deep in the Active crater (Fig. 8b) [1]. All the above data support the supposition that on April 16, 2007 activization of the Mutnovskii Volcano took place. The ash cloud posed a real danger for low-flying aircraft.

Based on visual observations, during 2007 the steam-gas column was not higher than $700 \mathrm{~m}$ above the rim of Active crater of the volcano. A weak thermal anomaly with a size of up to 4 pixels was recognized on satellite images in the volcanic area in April-May and July-November.

Gorelyi Volcano $\left(52^{\circ} 33^{\prime} \mathrm{N}, 158^{\circ} 02^{\prime} \mathrm{E}\right.$, elevation $1829 \mathrm{~m}$ ) was in a state of low activity in 2007. Field observations showed that the lake water area in the active crater is increasing little by little every year. Steam-gas columns 400 and $300 \mathrm{~m}$ high were observed on November 28 and December 28, respectively (see http://www.ksnet.ru/ivs/kvert/current/grl/ index.html). On the other days of the year the volcano was quiet or covered with clouds. A weak thermal anomaly with a size of 1-2 pixels was repeatedly detected on satellite images in the area of the active crater of the volcano.

\section{PARMUSHIR ISLAND OF THE NORTH KURILS}

Chikurachki Volcano $\left(50^{\circ} 19^{\prime} \mathrm{N}, 155^{\circ} 28^{\prime} \mathrm{E}\right.$, elevation $1816 \mathrm{~m}$ ) is the most active of the North Kuril volcanoes. KVERT has conducted satellite monitoring of this volcano since September 2002 [3]. No systematic visual observations of Chikurachki Volcano are carried out from Severo-Kuril'sk (60 km away from the volcano) because it is hidden behind the Vernadskii Range and no seismic monitoring is carried out either. KVERT workers receive irregular information on the volcano's conditions from the inhabitants of Paramushir Island, fishermen, and the pilots of airplanes and helicopters.

Two short-term explosive eruptions of the volcano took place in 2007.

The first explosive eruption of a moderate strength commenced on March 4 and continued until the middle of April. The eruptive column rose up to $3.3 \mathrm{~km} \mathrm{ASL}$, ash plumes extended for more than $200 \mathrm{~km}$, primarily in the eastern directions from the volcano (Fig. 3e). During the entire eruption period the ACC was orange. The first minor ash ejections were noticed by people from the Podgornyi settlement on March 4. Hydrographers working in the Cape Vasil'ev area observed an ash plume rising from the volcano up to $3.3 \mathrm{~km}$ ASL during the entire next day. Based on satellite data, in the volcanic area ash deposits were noted on the 5th and 25th of March; on March 5 and 7-8 ash plumes stretched up to $100 \mathrm{~km}$ to the north and northeast of the volcano; on March 11-12 up to $160 \mathrm{~km}$ to the east; on April 3-5 and 8, up to $260 \mathrm{~km}$ to the northeast [3]. In the beginning of April ashfall took place twice in the 
Podgornyi settlement; a small ashfall also occurred in the vicinity of the town of Severo-Kuril'sk on April 4. The height of the ash plume reached $2.8 \mathrm{~km}$ ASL on April 6; the plume extended to the south of the volcano. At later times, no explosive activity was recorded and on April 27 the ACC was changed to yellow and on May 11 to green.

The second explosive eruption of the volcano took place approximately from August 19 to the end of October. The eruptive column rose up to $4.8 \mathrm{~km}$ ASL and ash plumes stretched for more than $250 \mathrm{~km}$, primarily to the northeast and southeast of the volcano (Fig. 3e). During the entire eruption the ACC was orange. N.A. Malik, a scientific worker of the KVERT and IVS was the first to report that on August 19 an eruption was detected by ash plumes 70 and $120 \mathrm{~km}$ long on the TERRA MODIS and NOOA satellite images respectively; the plumes extended to the southeast of the volcano [3]. On the same day a strong ashfall occurred in the Podgornyi settlement. On August 20 helicopter pilots observed an ash column with a height of about $4.8 \mathrm{~km}$ ASL extending for $100 \mathrm{~km}$ to the southeast of the volcano. On August 21 , the ash column rose up to $3.0 \mathrm{~km}$ ASL extending for more than $200 \mathrm{~km}$ to the north-northeast of the volcano and resulting in ashfall on Atlasov Island. On August 22, ashfalls took place in the town of Severo-Kuril'sk and on Atlasov Island; the ash thickness at the foot of Alaid Volcano was 1-2 mm. Continuous moderate explosive activity of the volcano was observed from August 23 to 26 . According to satellite data, ash plumes extended to the east of the volcano for $120 \mathrm{~km}$ on August 19-21 and 24, $50 \mathrm{~km}$ on August 26, and for $100-180 \mathrm{~km}$ on August 28-31. In the volcanic area helicopter pilots observed ash ejection to a height of up to $3.0 \mathrm{~km}$ ASL on September 1; an ash plume extended for $50 \mathrm{~km}$ to the east of the volcano. Observers from the summit of Ebeko Volcano reported uninterrupted ash ejections to a height of $3.2 \mathrm{~km}$ ASL on September 3 with an ash plume stretching to the southeast of the volcano. On September 4, a hunter reported a fine ash layer at the mouth of the Shimoyur River (4 km northeast of the summit of the volcano). On September 8, an ash plume extended to the east-southeast of the volcano [3]. An approximately 300 meter high steam-gas column with minor ash was observed above Chikurachki Volcano, which was noticed on September 11 from the Ebeko Volcano area. On September 19-21 ash plumes stretched at the crater level for $110 \mathrm{~km}$ to the southeast of the volcano. From September 22 to October 20 the volcano was often covered by dense clouds, but from October 7 satellite images showed ash plumes up to $180 \mathrm{~km}$ long almost daily in the eastern sector. After October 20 no ash plumes were detected on satellite images and that is why on November 15 the ACC was changed to yellow and on November 22 to green.

During 2007 ash plumes from Chikurachki Volcano drifted primarily to the northeast and southeast of the volcano (Fig. 3e), i.e., in the eastern sector of Para- mushir Island a real hazard for low-flying aircraft existed.

Ebeko Volcano $\left(50^{\circ} 41^{\prime} \mathrm{N}, 156^{\circ} 01^{\prime} \mathrm{E}\right.$, elevation $1156 \mathrm{~m}$ ) located $7 \mathrm{~km}$ away from Severo-Kuril'sk town was in a condition of weak permanent activity. During 2007 the volcano was hidden from observation with clouds about $75 \%$ of the time. At other times fumarole activity was detected, with a steam-gas column rising up to $750 \mathrm{~m}$ above the crater. Periodically, with westerly and northwesterly winds, and also at times in calm conditions, volcanic gases could be smelled in SeveroKuril'sk (for about $20 \%$ of the days of this year). This happened especially often in the winter and autumn months, due to the predomination of northwestern winds. During examination of the volcano on April 19, July 4 and 14, August 10, and September 3 and 11, the most intense fumarole activity was noted on the Iyul'skoe fumarole field that originated in 2005 on the outer northeastern slope of the Severnyi volcanic cone, as well as in the Active funnel.

\section{CONCLUSION}

The Northern Group of Volcanoes was the most active in 2007. Explosive-effusive eruption of Klyuchevskoi Volcano was unusual: three lava flows poured onto different volcano slopes at the same time; during strong explosions ash clouds rose up to $12 \mathrm{~km}$ ASL; ash plumes stretched for $5400 \mathrm{~km}$ and more in all directions from the volcano; eruption continued for about 5 months. Three explosive eruptions of the Merapi type took place at the Bezymyannyi Volcano [7]: two of them were related to juvenile matter supply, and one, with the collapse of the frontal parts of lava flows, originated during the eruptions of 1989-2001; eruptive columns rose to $10 \mathrm{~km} \mathrm{ASL}$, and ash plumes extended to the southeast and east of the volcano. At the Shiveluch Volcano continued explosive eruption, and almost uninterrupted squeezing of juvenile material were accompanied by rare powerful explosive events, when ash rose up to $12 \mathrm{~km}$ ASL, ash plumes stretched primarily to the southeast and east of the volcano. On Karymskii Volcano moderate explosive eruption was occurring with ash ejection up to $5 \mathrm{~km}$ ASL for almost the entire year; ash plumes propagated primarily to the southeast and east of the volcano. Satellite monitoring of Kamchatka and North Kuril volcanoes allowed KVERT staff to detect and observe an explosive event (probable a phreatic explosion) on Mutnovskii Volcano and two explosive eruptions of the Chikurachki Volcano (Paramushir Island). Owing to the close cooperation of KVERT project colleagues, the Elizovo Airport Meteorological Center, and the volcanic ash advisory centers in Tokyo, Anchorage, and Washington (Tokyo VAAC, Anchorage VAAC, and Washington VAAC), all necessary precautions were taken for flight safety near Kamchatka and no fatal accidents related to the explosive activity of these volcanoes took place. 


\section{AKNOWLEGEMENTS}

This work was carried out in the framework of KVERT program "Volcanic Ash and Aviation Safety."

\section{REFERENCES}

1. Gavrilenko, G.M., Mel'nikov, D.V., Zelenskii, M.E., et al., Long-term Hydrogeochemical Monitoring of Mutnovskii Volcano (Kamchatka) and Phreatic Eruption of the Volcano in April 2007, Vestn. KRAUNTs. Nauki o Zemle, 2007, no. 1 (9), pp. 127-132.

2. Girina, O.A. and Gordeev, E.I., KVERT Project-Reduction of Volcanic Hazard for Aircraft During Explosive Eruptions of Kamchatka and North Kuril Volcanoes, Vestn. Dalnevost. Otd. Akad. Nauk., 2007, no. 2, pp. 100-109.

3. Girina, O.A., Malik, N.A., and Kotenko, L.V., Activity of Chikurachki Volcano (Paramushir I. North Kuril) in 2002-2007, KVERT Data, Vestn. KRAUNTs. Nauki o Zemle, 2008, no. 1 (11), pp. 67-73.

4. Girina, O.A., Senyukov, S.L., and Neal, C.A., Kamchatka Volcanic Eruption Response Team (KVERT) in 2002-2004, in Materialy 4-go mezhdunarodnogo soveshchaniya po protsessam $v$ zone subduktsii Yaponskoi, Kurilo-Kamchatskoi i Aleutskoi ostrovnykh dug, avgust 2004 (Materials of the 4th International Confer- ence on Processes in Subduction Zones of Japan, KurilKamchatka and Aleutian Island Arcs, August 2004), Petropavlovsk-Kamchatskii: 2004, pp. 31-32.

5. Kir'yanov, V.Yu., Neal, C.A., Gordeev, E.I., et al., Kamchatskaya gruppa reagirovaniya na vulkanicheskie izverzheniya (KVERT) (Kamchatka Volcanic Eruption Response Team (KVERT)), USGS, Fact Sheet, 2003, 151-02.

6. Kozhevnikova, T.Yu., Electronic Data Base of Seismic Signal Standards and Accompanying Volcanic Events for Karymskii Volcano, in: Problemy kompleksnogo geofizicheskogo monitoringa Dal'nego Vostoka Rossii. Tezisy dokladov (Problems of Comprehensive Geophysical Monitoring of the Far East of Russia. Abstracts of Papers), Petropavlovsk-Kamchatskii: Geophysical Survey, RAS, 2007, p 101.

7. Macdonald, G.A., Volcanoes, New Jersey: Prentice-Hall, 1972.

8. Senyukov, S.L., Droznina, S.Ya., and Droznin, D.V., Identification of Ash Ejections and Estimation of their Height Based on Seismic Data for Shiveluch Volcano (Kamchatka), in: Kompleksnye seismologicheskie $i$ geofizicheskie issledovaniya Kamchatki (Multidisciplinary Seismological and Geophysical Studies of Kamchatka), Petropavlovsk-Kamchatskii: KBGS, RAS, 2004, pp. 292-300. 